\title{
Molecular systematics of the genera Laurencia, Osmundea and Palisada (Rhodophyta) from the Canary Islands - Analysis of rDNA and RUBISCO spacer sequences
}

\author{
by \\ Sh. Lewis ${ }^{1}$, P. Gacesa $(\dagger)^{1}$, M.C. Gil-Rodríguez ${ }^{2}$, F. Valdés ${ }^{3} \&$ I. Frías ${ }^{4}$ \\ ${ }^{1}$ School of Molecular and Medical Biosciences, University of Wales, Cardiff CF1 3US, UK \\ ${ }_{2}^{2}$ Departamento de Biología Vegetal, Facultad de Farmacia, Universidad de La Laguna, 38071 La Laguna, Tenerife, Spain. mcgil@ull.es \\ ${ }_{3}^{3}$ Departamento de Biología Vegetal, Universidad de La Laguna, 38071 La Laguna, Tenerife, Spain. fvaldes@ull.es \\ ${ }^{4}$ ICIC, Departamento de Bioquímica, Universidad de La Laguna, 38071 La Laguna, Tenerife, Spain. jfrias@ull.es
}

\begin{abstract}
Lewis, Sh., Gacesa, P., Gil-Rodríguez, M.C., Valdés, F. \& Frías, I. 2008. Molecular systematics of the genera Laurencia, Osmundea and Palisada (Rhodophyta) from the Canary Islands Analysis of rDNA and RUBISCO spacer sequences. Anales Jard. Bot. Madrid 65(1): 97-109.

The molecular systematics of Laurencia, Osmundea and Palisada (Rhodomelaceae, Ceramiales) species from the Canary Islands has been determined by analysis sequences of the ribulose, 1-5, bisphosphate carboxylase (RUBISCO) spacer from the plastid genome and the internal transcribed spacers (ITS1 and ITS2) and the rDNA 5.8S coding region from the nuclear genome. Comparison of sequence data showed an identity of $72-83 \%$ between the species. Three taxonomic group were identified that correspond to established phylogenetic taxons. Phylogenetic trees using both parsimony and maximum-likelihood methods were derived from the sequence data; the trees indicate that $O$. pinnatifida appears to be the most distantly related species from the Laurencia and Palisada species. The exact phylogenetic position of Laurencia sp. A ("amarilla") need additional studies.
\end{abstract}

Keywords: Laurencia, Osmundea, Palisada, Phylogeny, Canary Islands.

\section{Introduction}

The Laurencia complex Lamouroux (Rhodophyta) has been separate into five genera: Laurencia sensu stricto Lamouroux, Chondrophycus Tokida \& Saito, Osmundea Stackhouse, Palisada K.W. Nam and Coryneclaida J. Agardh, based on vegetative and reproductive structures (Garbary \& Harper, 1998; Nam \& al., 1994).

\section{Resumen}

Lewis, Sh., Gacesa, P., Gil-Rodríguez, M.C., Valdés, F. \& Frías, I. 2008. Sistemática molecular de los géneros Laurencia, Osmundea y Palisada (Rhodophyta) de las Islas Canarias, basadas en la secuencia espaciadora del RUBISCO y del rDNA. Anales Jard. Bot. Madrid 65(1): 97-109 (en inglés).

Se aportan datos filogenéticos de algunas especies de Laurencia, Osmundea y Palisada (Rhodomelaceae, Ceramiales) de las Islas Canarias mediante el análisis de secuencias de la región espaciadora de ribulose, 1-5, bisfosfato carboxilasa (RUBISCO) del genoma plastídico y las regiones espaciadoras internas (ITS1, ITS2) y de la región codificadora del rDNA en el genoma nuclear. Los tres géneros analizados, Laurencia, Osmundea y Palisada muestran las correspondientes identidades moleculares con una identidad del $72-83 \%$ entre ellas. Empleando métodos de parsimonia y máxima similitud, los correspondientes árboles filogenéticos ponen de manifiesto que $O$. pinnatifida es el taxon más distante entre las especies de Laurencia y Palisada analizadas. La posición exacta del taxon mencionado como Laurencia sp. A "amarilla") precisa de estudio adicional.

Palabras clave: Laurencia, Osmundea, Palisada, Filogenia, Islas Canarias.

The complex include red algae species of small to medium size; they are spread worldwide except in the Artic and Antarctic (McDermid, 1988). They are frequently found in temperate waters, however they make up an important part of the tropical and subtropical marine flora (Saito, 1969; Diaz-Piferrer, 1970; Lawson \& John, 1982; Rodríguez de Rios \& Saito, 1982; Cordeiro-Marino \& al., 1983; McDermid, 1988; Vandermeulen \& al., 1990). 
Many authors have pointed out the problems of identification presented in species from these complex in the Atlantic Ocean (Saito, 1964, 1965, 1967; Magne, 1980; Rodríguez de Rios \& Saito, 1982; Cribb, 1983; Gil-Rodríguez \& Haroun, 1992, 1993; Haroun \& Prud'homme van Reine, 1993; Maggs \& Hommersand 1993; Hernández-González \& al., 1994; among others). At the same time, new combinations and records, and new species were described for the Laurencia complex (Wynne \& Ballantine 1991; Gil-Rodríguez \& Haroun 1992; Furnari \& al. 2001, 2002; Yoneshigue-Valentin \& al. 2003; Klein \& Verlaque 2005; Cassano \& al. 2006). Recently, a morphological phylogenetic analysis of this complex was reported but this complex, in Canary Islands, required additional analysis in order to be correctly ubicated into inequivocal taxons instead of some morphological and physiological similitude.

Both, the small and large subunits of RUBISCO, are encoded by the red algae plastid genome. The RUBISCO genes of Rhodophyta, Cryptophyta and Chromophyta are co-transcribed (Zetsche \& al.,1991) and are separated by a small non-coding spacer region (Fig. 1).

The RUBISCO “operon" has been extensively studied in algae (e.g., Valentin \& Zetche, 1990; Kono \& al., 1991; Hommersand \& al., 1994; Pichard \& al., 1997). This spacer region has been utilized in taxo- nomic and systematic studies of algae (Destombe \& Douglas, 1991; Goff \& al., 1994; Stache-Grain \& al., 1997).

In addition to RUBISCO, the comparison of DNA sequences of $\mathrm{rDNA}$, has proved to be a useful systematic tool. rDNA consists of genes that encode for the large (28S) and small ribosomal sub-unit RNA (18S and 5.8S) plus transcribed and non-transcribed spacer regions. The intergenic spacer region (non-coding) has evolved most rapidly while the coding regions are the most evolutionary conserved sequences of the cistron (Druehl \& Saunders, 1992). Interspecific and intraspecific sequence variation of these regions has been examined in plants (Baldwin, 1992), fungi (O'Donnell, 1992), diatoms (Zechman \& al., 1994), green algae (Coleman \& al., 1994; Bakker \& al., 1995), ahermatypic corals (Beauchamp \& Powers, 1996) and red algae (Steane \& al., 1991). rDNA has also been utilised for systematic and taxonomic studies of algae (Goff \& al., 1994; Rumpf \& al., 1996; Stache-Grain \& al., 1997).

Goff \& al. (1994) and Stache-Grain \& al. (1997) examined the value of both the ITS and RUBISCO spacer sequences in delineating relationships of populations, species and genera in Gracilaria Greville, Gracilariopsis Dawson, Ectocarpus Lyngbye and $\mathrm{Ku}$ ckuckia Hamel. They found that both were highly conserved at species and population levels.

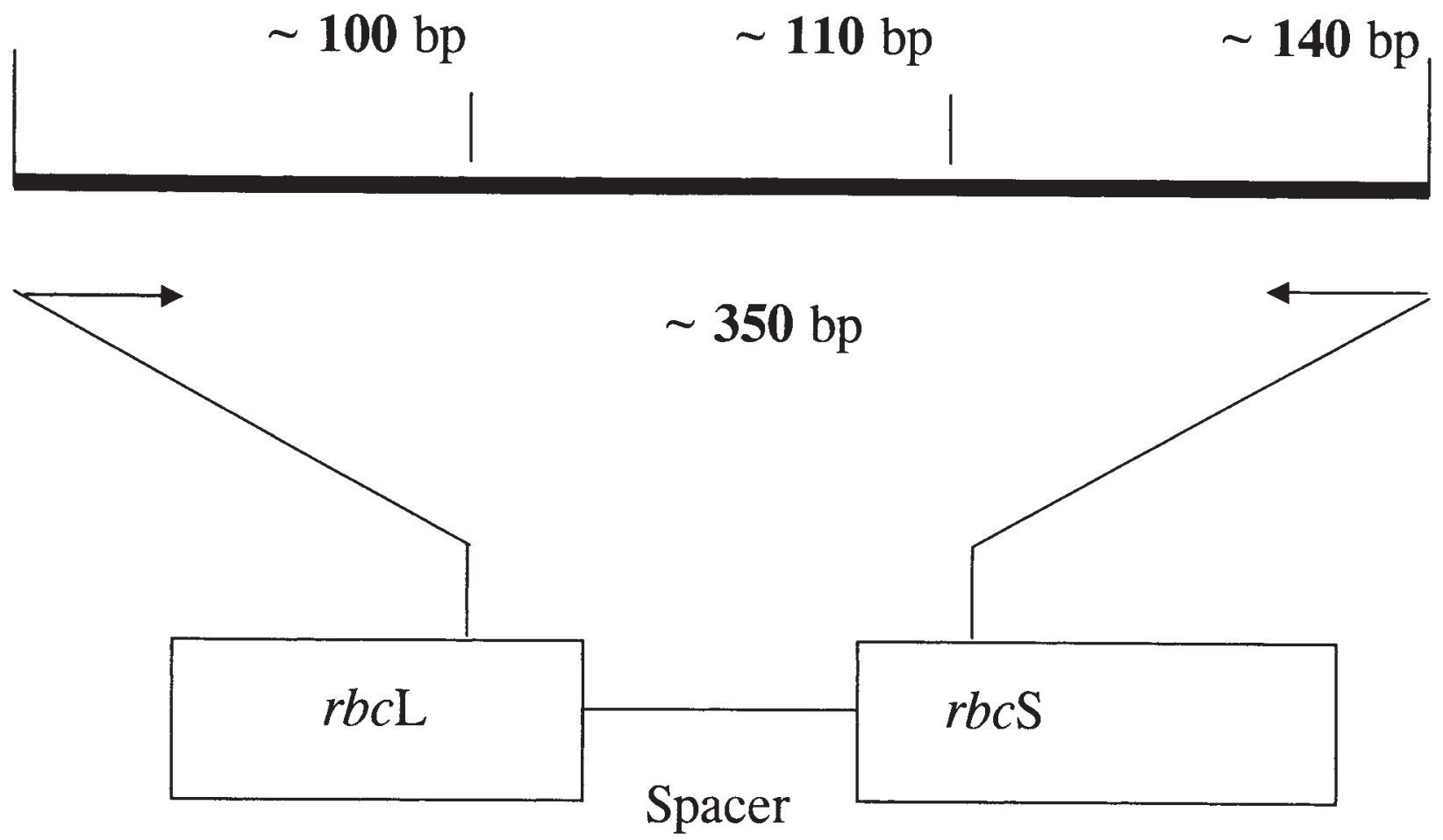

Fig. 1. Plastid RUBISCO spacer region in red algae. Amplification primers are represented by the forward and reverse arrows. 
In this work we initiate a preliminary molecular analysis of this complex group by means of the amplification and sequencing of the RUBISCO spacer and rDNA internal transcribed spacers (ITS1 and ITS2) including the intervening $5.8 \mathrm{~S}$ coding region of the nuclear genome of six species in the genus Laurencia, Osmundea and Palisada. The results obtained were used to derivate a phylogenetic tree that indicate the molecular taxonomy between species.

\section{Materials and Methods}

Treatment of algal material and nuclear DNA extraction: Individual plants were collected from various locations (Table 1) in Tenerife and La Palma (Canary Islands) and New Zealand. A voucher specimen from each species from the Canary Islands used for sequencing and amplification were deposited in the La Laguna University Herbarium TFC. Samples of Laurencia thyrsifera J. Agardh from New Zealand were provided by Dr Ruth Falshaw (Industrial Research Limited, New Zealand). Only algae that were visibly clear of epiphytes were used for DNA extraction. DNA was extracted from the apical parts of the thallus, frozen by immersion in liquid nitrogen and stored at $-20^{\circ} \mathrm{C}$.

For extraction and amplification of plastic DNA fresh/frozen thallus $(5 \mathrm{~g}$ ) was suspended in $15 \mathrm{ml}$ of $100 \mathrm{mM}$ Tris- $\mathrm{HCl}$ (pH 8.0) containing $50 \mathrm{mM}$ EDTA $(\mathrm{pH} 8.0)$ and $0.5 \mathrm{M} \mathrm{NaCl}$ to which $10 \%(\mathrm{w} / \mathrm{v})$ SDS was added. Ribonuclease A $(0.15 \mathrm{mg})$ and Proteinase $\mathrm{K}(1.5 \mathrm{mg})$ were added to the sample and the tube incubated at $37^{\circ} \mathrm{C}$ for $1.5 \mathrm{~h}$. DNA was isolated by phenol and chloroform / isoamylalcohol $(24: 1 \mathrm{v} / \mathrm{v})$ precipitation and extracted in cold absolute alcohol. Plastid, nuclear and mitochondrial DNA was isolated by differential centrifugation in caesium chloride / Hoechst (33258) dye density gradient at $174,000 \times g$ for $16 \mathrm{~h}$.

Table 1. Laurencia, Palisada and Osmundea species and locations.

\begin{tabular}{|l|c|l|}
\hline Species & Location & \multicolumn{1}{|c|}{$\begin{array}{c}\text { Herbarium } \\
\text { reference }\end{array}$} \\
\hline L. viridis & $\begin{array}{c}\text { Fajana de Barlovento } \\
\text { (La Palma) }\end{array}$ & TFC Phyc. 9882 \\
\hline $\begin{array}{l}\text { L. sp. A } \\
\text { ("amarilla") }\end{array}$ & Paraíso Floral (Tenerife) & TFC Phyc. 9880 \\
\hline P. cf. perforata & Paraíso Floral (Tenerife) & TFC Phyc. 9884 \\
\hline P. perforata & $\begin{array}{c}\text { Fajana de Barlovento } \\
\text { (La Palma) }\end{array}$ & TFC Phyc. 9883 \\
\hline O. pinnatifida & Pto. de la Cruz (Tenerife) & TFC Phyc. 9881 \\
\hline L. thyrsifera & Hokianga (New Zealand) & \\
\hline
\end{tabular}

RUBISCO DNA Amplification: The RUBISCO spacer was amplified using forward primer: ${ }^{5}$ TGTGGACCTCTACAAACAGC and reverse primer: ${ }^{5} \mathrm{CC}$ CATAGTTCCCAAT. The reactions were performed after initial denaturation at $95^{\circ} \mathrm{C}$ for $10 \mathrm{~min}$. The samples were then cycled sequentially using a temperature regime of $95^{\circ} \mathrm{C} / 5 \mathrm{~min}, 90^{\circ} \mathrm{C} / 1 \mathrm{~min}, 50^{\circ} \mathrm{C} / 2 \mathrm{~min}$ (5 cycles); $72{ }^{\circ} \mathrm{C} / 1 \mathrm{~min} ; 90^{\circ} \mathrm{C} / 1 \mathrm{~min}, 60^{\circ} \mathrm{C} / 1 \mathrm{~min}, 72$ ${ }^{\circ} \mathrm{C} / 1 \mathrm{~min}\left(30\right.$ cycles); $72^{\circ} \mathrm{C} / 10 \mathrm{~min}$.

rDNA Amplification: Target regions of rDNA were amplified using forward primer: ${ }^{\prime}$ GTTTCCGTAGGTGAACCTGC and reverse primer: ${ }^{\prime}$ ATATGCTTAAGTTCAGCGGGT. The reactions were performed after initial denaturation at $95^{\circ} \mathrm{C}$ for $10 \mathrm{~min}$. The samples were then cycled sequentially using a temperature regime of $94^{\circ} \mathrm{C} / 1.25 \mathrm{~min}, 60{ }^{\circ} \mathrm{C} / 2 \mathrm{~min}$ and $72{ }^{\circ} \mathrm{C} / 4 \mathrm{~min}$ repeated for 30 cycles followed by a final period of $72{ }^{\circ} \mathrm{C} / 10 \mathrm{~min}$.

Cloning of purified PCR products: Purified PCR products (Qiagen gel extraction kit) were ligated using the pGEM-T vector system (Promega) according to the company's instructions. These ligated products were transformed either by a heat shock method into E. coli XL1 or electrophorated using electro-competent $E$. coli JS5 high efficiency cells (Bio-Rad).

Sequencing of plasmid DNA: Chain-termination sequencing of purified PCR products was performed using the USB Sequenase ${ }^{\mathrm{R}^{*}}$ Version 2.0 kit according to the company's protocol. Some clones were sequenced using forward and reverse M13 primers labeled with fluorescein (Pharmacia LKB), using a Pharmacia LKB Automated Laser Fluorescent (ALF) DNA sequencer and others sequenced using a Hybaid LI-COR 4000LS infra-red automated sequencer.

Analysis of sequence data: Sequence data were analyzed using the UWGCG (University of Wisconsin Genetics Computer Group, Version 7.1 UNIX, Devereux \& al. 1984) package at Daresbury. Alignments of sequences were produced using GAP, which uses the algorithm of Needleman. The default parameters used were "Gap weight" (penalty for introducing a new gap): 1.0 and "Gap length" weight (maximum length of internal gaps): 0.1 . Phylogenies were recovered using PHYLIP package (version 3.5c) (Felsenstein, 1993). The branch and bound algorithm (DNAPENNY) was used to find the most parsimonious tree and a phylogeny was also recovered by maximum-likelihood (DNAML). Bootstrap values were calculated for each tree using additional routines in the package (SEQBOOT, CONSENSE).

DNA sequences showed in this work are deposited in the GenBank with the following accession num- 
Table 2. Sizes and percentage identity of the rbc spacers in the genera Laurencia, Palisada, Osmundea, Antithamnion and Gracilariopsis

\begin{tabular}{|l|c|c|c|c|c|c|c|c|c|}
\hline Species & Length $(\mathrm{bp})$ & $\mathbf{1}$ & $\mathbf{2}$ & $\mathbf{3}$ & $\mathbf{4}$ & $\mathbf{5}$ & $\mathbf{6}$ & $\mathbf{7}$ & $\mathbf{8}$ \\
\hline 1. L. sp. A ("amarilla") & 109 & - & 73.2 & 80.9 & 81.7 & 75.8 & 79.8 & 73.2 & 62.1 \\
\hline 2. O. pinnatifida & 112 & 73.2 & - & 77.3 & 75.7 & 80.8 & 80.6 & 68.4 & 66.3 \\
\hline 3. L. viridis & 109 & 80.9 & 77.3 & - & 95.4 & 72.5 & 83.0 & 65.3 & 72.0 \\
\hline 4. L. thyrsifera & 108 & 81.7 & 75.7 & 95.4 & - & 70.9 & 81.7 & 70.8 & 72.0 \\
\hline 5. P. perforata & 103 & 75.8 & 80.8 & 72.5 & 70.9 & - & 72.0 & 67.7 & 69.1 \\
\hline 6. P. cf. perforata & 93 & 79.8 & 80.6 & 83.0 & 81.7 & 72.0 & - & 72.4 & 69.2 \\
\hline 7. Antithamnion sp. & 99 & 73.2 & 68.4 & 65.3 & 70.8 & 67.7 & 72.4 & - & 71.9 \\
\hline 8. G. lemaneiformis & 107 & 62.1 & 66.3 & 72.0 & 72.0 & 69.1 & 69.2 & 71.9 & - \\
\hline
\end{tabular}

bers: AF081268-AF081272 and AF082340AF082344.

\section{Results}

Amplification of the RUBISCO spacer using primers conserved for the 3' end of the $r b c \mathrm{~L}$ and the 5' end of the $r b c S$ genes (Fig. 1) produced products ranging in size between 350-375 bp depending on the Laurencia, Osmundea and Palisada species. The sequence data revealed a spacer region of $93-112 \mathrm{bp}$ in all of the Laurencia, Osmundea and Palisada samples analyzed (Table 2).

Although the spacer is a non-coding region there is quite a high percentage identity amongst the Laurencia Osmundea and Palisada samples (72-83\%) and $L$. viridis and $L$. thyrsifera have $95 \%$ identity. Additional comparison with spacer sequence from the far related genera: Gracilariopsis lemaneiformis (Bory de Saint-Vincent) Dawson, Acleto \& Foldvik and Antithamnion sp., in order to compare the Laurencia, Osmundea and Palisada differences, showns an equivalent $62-73 \%$ of identity. Multiple alignments of these sequences were produced using CLUSTALV (Fig. 2).

There are no insertions / deletions in the coding regions of $r b c \mathrm{~L}$ and $r b c \mathrm{~S}$ but there are point mutations with approximately equal numbers of transitions and transversions. Of the 379 alignable positions (Fig. 2) 94 were possible phylogenetically important locations and over half of these were in the non-coding spacer region (i.e. $55 / 118$ positions $=46.6 \%$ informative variability in this region); nine informative positions occurred in the $r b c \mathrm{~L}(9 / 105$ nucleotides $=8.6 \%$ variability), and 31 occurred in the $r b c \mathrm{~S}$ region $(31 / 156$ nucleotides $=19.9 \%$ variability).

The length of the ITS regions and 5.8S rDNA is relatively well conserved in the Laurencia species. ITS1 is of similar size in all the species studied $(160-170 \mathrm{bp})$ with the exception of O. pinnatifida (211 bp). The latter species produced the largest amplification product and the increase in size resulted from insertions into ITS1 (Fig. 1). There is less variation in the length of the ITS2 regions than ITS1 of Laurencia (202-222 bp) and ITS2 is larger than ITS1 in all of the Laurencia and Osmundea species examined. The percentage identity of the sequence data obtained from each region of these amplified products was calculated using GAP (UWGCG, Daresbury) (Table 3).

There is a high percentage of identity within the species in all three regions. The identity in the ITS1 is the lowest in all the species with values ranging from $70.3-97 \%$, while the identity in the ITS2 is slightly higher at $74.1-98.2 \%$. The $5.8 \mathrm{~S}$ has the highest percentage identity amongst the Laurencia and Osmundea where $L$. viridis has a $100 \%$ identity to $L$. sp. A ("amarilla"). Sequence data of the $5.8 \mathrm{~S}$ coding region of the Laurencia and Osmundea species were compared with each other and with the $5.8 \mathrm{~S}$ data of Gracilariopsis lemaneiformis (Bory de Saint-Vincent) Dawson, Acleto \& Foldvik which was used as an outgroup (data kindly supplied by Dr. Lynda Goff, UCSC), and the identity calculated using GAP (Table 4). The multiple alignments of these sequences as produced by CLUSTALV are shown in Figure 2.

Table 3. Percentage identity of ITS1, 5.8S and ITS2 sequences.

\begin{tabular}{|l|c|c|c|c|}
\hline \multirow{2}{*}{ Species } & \multirow{2}{*}{ length (bp) } & \multicolumn{3}{|c|}{ \% Identity } \\
\cline { 3 - 5 } & & ITS1 & $\mathbf{5 . 8 5}$ & ITS2 \\
\hline L. sp. A ("amarilla") & 536 & 100 & 100 & 100 \\
\hline L. viridis & 537 & 84.2 & 100 & 92.9 \\
\hline P. perforata & 521 & 97.0 & 98.7 & 98.2 \\
\hline P. cf. perforata & 543 & 85.5 & 97.4 & 88.1 \\
\hline L. thyrsifera & 544 & 72.5 & 96.8 & 84.7 \\
\hline O. pinnatifida & 579 & 70.3 & 91.5 & 74.1 \\
\hline
\end{tabular}


Table 4. Percentage identity matrix of the $5.8 \mathrm{~S}$ coding region.

\begin{tabular}{|l|c|c|c|c|c|c|c|}
\hline Species & $\mathbf{1}$ & $\mathbf{2}$ & $\mathbf{3}$ & $\mathbf{4}$ & $\mathbf{5}$ & $\mathbf{6}$ & $\mathbf{7}$ \\
\hline 1. L. sp. A ("amarilla") & - & 100 & 98.7 & 97.4 & 96.8 & 91.4 & 73.9 \\
\hline 2. L. viridis & 100 & - & 98.7 & 97.4 & 96.8 & 91.4 & 73.9 \\
\hline 3. P. perforata & 98.7 & 98.7 & - & 97.4 & 95.5 & 90.8 & 72.5 \\
\hline 4. P. cf. perforata & 97.4 & 97.4 & 97.4 & - & 95.5 & 91.4 & 73.2 \\
\hline 5. L. thyrsifera & 96.8 & 96.8 & 95.5 & 95.5 & - & 91.4 & 75.2 \\
\hline 6. O. pinnatifida & 91.4 & 91.4 & 90.8 & 91.2 & 91.4 & - & 76.9 \\
\hline 7. G. lemaneiformis & 73.9 & 73.9 & 72.5 & 73.2 & 75.2 & 76.9 & - \\
\hline
\end{tabular}

\begin{tabular}{|c|c|}
\hline & $\begin{array}{r}\text { S'end } \\
60\end{array}$ \\
\hline L. sp. A ("amarilla") & TGTGGACCTCTACAAACAGC ATTAGACTTATGGAAGGACA TTACATTCAACTATACTTCT \\
\hline O. pinnatifida & 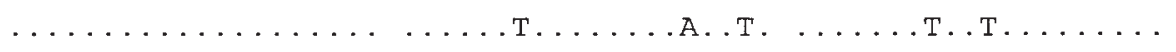 \\
\hline L. viridis & $\ldots \ldots \ldots \ldots \ldots \ldots \ldots \ldots \ldots \ldots$ Т. \\
\hline L. thyrsifera & 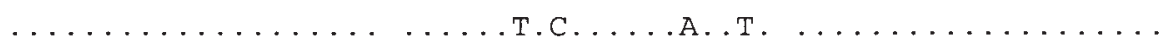 \\
\hline P. perforata & 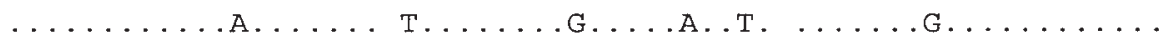 \\
\hline P. cf. perforata & $\ldots \ldots \ldots \ldots \ldots \ldots \ldots \ldots \ldots \ldots$ та \\
\hline Antithamnion sp. & 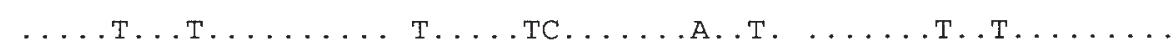 \\
\hline \multirow[t]{2}{*}{ G. lemaneiformis } & $\begin{array}{l}\ldots \ldots \text { Т. } \\
++++++++++{ }_{+++++++}+++++\quad \ldots \text { Т. } \\
++++++++++++++++++++++++++\end{array}$ \\
\hline & $\begin{aligned} & b c \mathrm{~L} \text { end } \quad 120 \\
\leftarrow & \end{aligned}$ \\
\hline L. sp. A ( amarilla ) & ACAGATACTGCTGACTTTGT AGAAACTCCAACAGCTAATG TTTAAATCAAACAAATAATA \\
\hline O. pinnatifida & $\ldots \ldots$ А. \\
\hline L. viridis & 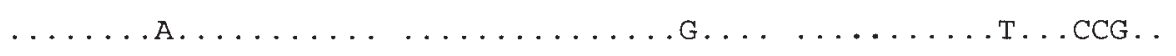 \\
\hline L. thyrsifera & 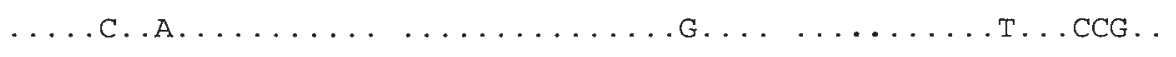 \\
\hline P. perforata & $\ldots \ldots \ldots \ldots \ldots \ldots \ldots \ldots \ldots \ldots \ldots \ldots \ldots$ T.T. - G. $--\ldots$ \\
\hline P. cf. perforata & 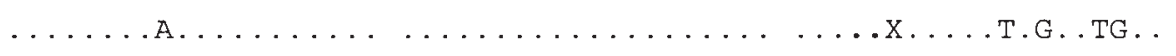 \\
\hline Antithamnion sp. & 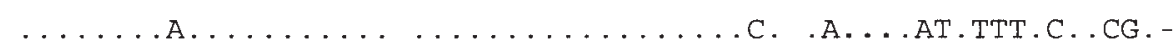 \\
\hline G. lemaneiformis & $\ldots \ldots$. . . . . . . . . . . . -ТТТТС. ТСТ. \\
\hline & $++++++++++++++++++++++++++++++++++\quad+\quad+$ \\
\hline
\end{tabular}

Fig. 2. Aligned sequences of the RUBISCO spacer and its flanking regions. Sequences were aligned using the CLUSTALV program. Dots denote the same nucleotide as that of Laurencia sp. A ("amarilla") in row one, a * denotes the same nucleotide in all the species, a $x$ represents unknown nucleotides and a hyphen represents a gap with the exception of $L$. viridis where for positions $248-375$ the sequence is not known. The stop and start codons of $r b c L$ and $r b c S$ respectively are highlighted as are the Shine-Dalgarno sequences. Antithamnion sp. is used as an outgroup and the forward and reverse primers are underlined. 
L. sp. A ("amarilla")

O. pinnatifida

L. viridis

L. thyrsifera

$P$. perforata

$P$. cf. perforata

Antithamnion sp.

G. lemaneiformis

L. sp. A ("amarilla")

O. pinnatifida

L. viridis

L. thyrsifera

P. perforata

$P$. cf. perforata

Antithamnion sp.

G. lemaneiformis
AGCATTC - - - ATTATAT TTCAATGTTAATTTTGCACT TACGTAAAGTCGCATTAGAA

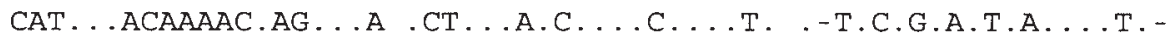

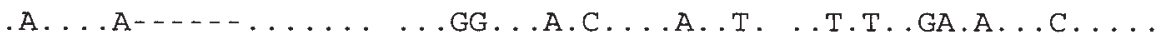

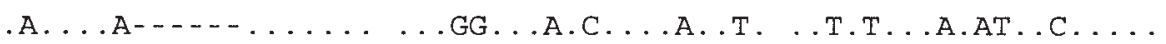

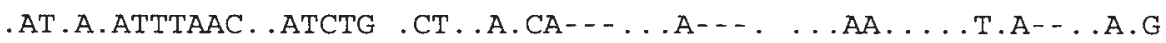

TA............. . . . T.G................. TA......

-- T... TTTA---CG.G. ....-..A.G...A.TGAA . T-C...A.-- . C.AGC

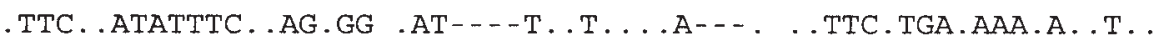

$++$

$r b c \mathrm{~S}$ start

240

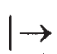

ATTCTTAAACAAGATTAATC -ATTAATAAgGAgTATAGATA AgTgAGATTAACACAAGGA

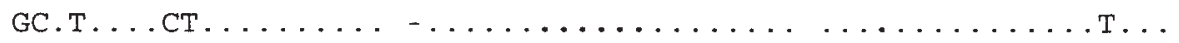

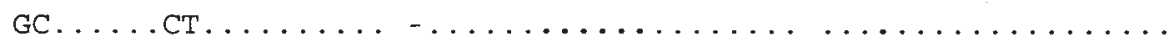

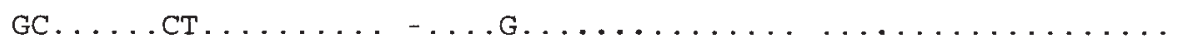

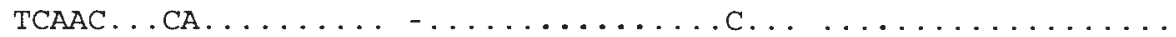

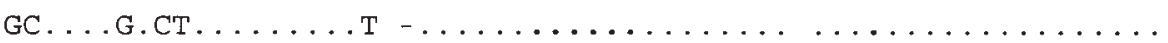

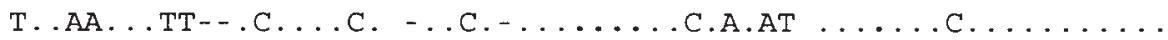

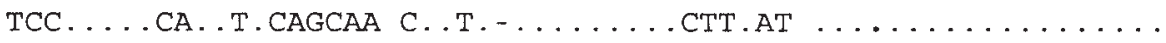

$++$

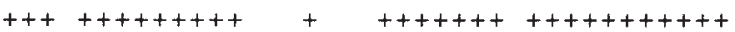

Shine-Dalgarno

Fig. 2. (Continuation).

Phylogenetic analysis of the data from RUBISCO and rDNA were carried out using both parsimony and maximum-likelihood methods. The phylogenetic trees produced for the different regions using both methods were similar and indicated that $O$. pinnatifi$d a$ was the most distantly related of the Laurencia and Osmundea species (Fig. 3a). The phylogenetic trees from the sequence data for the ITSs and $5.8 \mathrm{~S}$ secuences, and using G. lemaneiformis as the outgroup shown similar results and indicated that $O$. pinnatifida was the most distantly related of the Laurencia and Osmundea species (Fig. 3b).

\section{Discussion}

Amplification of the RUBISCO spacer and its flanking coding regions from the Laurencia, Osmundea and Palisada species studied produced a sin- gle product of approximately 350-375 bp in length. The non-coding spacer region in these species ranged between 93-112 bp, which are within the range reported for RUBISCO spacers from other algae (Destombe \& Douglas, 1991; Goff \& al., 1994). In addition, amplification of the ITS1, 5.8S and ITS2 regions in the nuclear genome gave consistently reproducible results similar to those found for other red algae (680-1450 bp) as examined by Steane \& al. (1991). In that study, DNA from the Australian alga Laurencia filiformis (C. Agardh) Montagne was amplified and the product was similar in size to the Laurencia and Osmundea species studied in this work. Even though the size differences of the PCR products within the Laurencia and Osmundea species studied here were quite small, $(\sim 5-50 \mathrm{bp})$, this was sufficient to distinguish between them.

The comparison of the sequence data obtained 


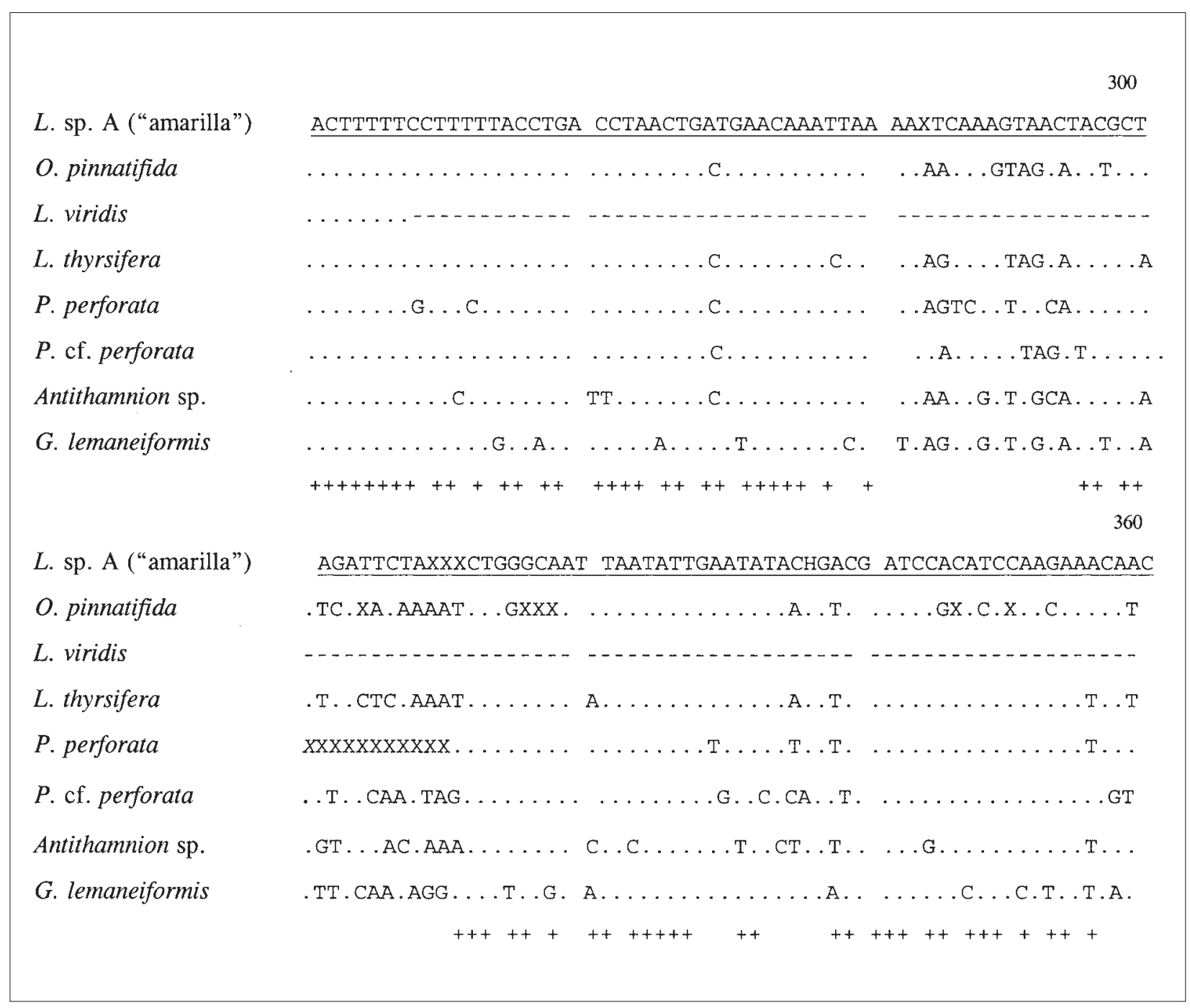

Fig. 2. (Continuation).

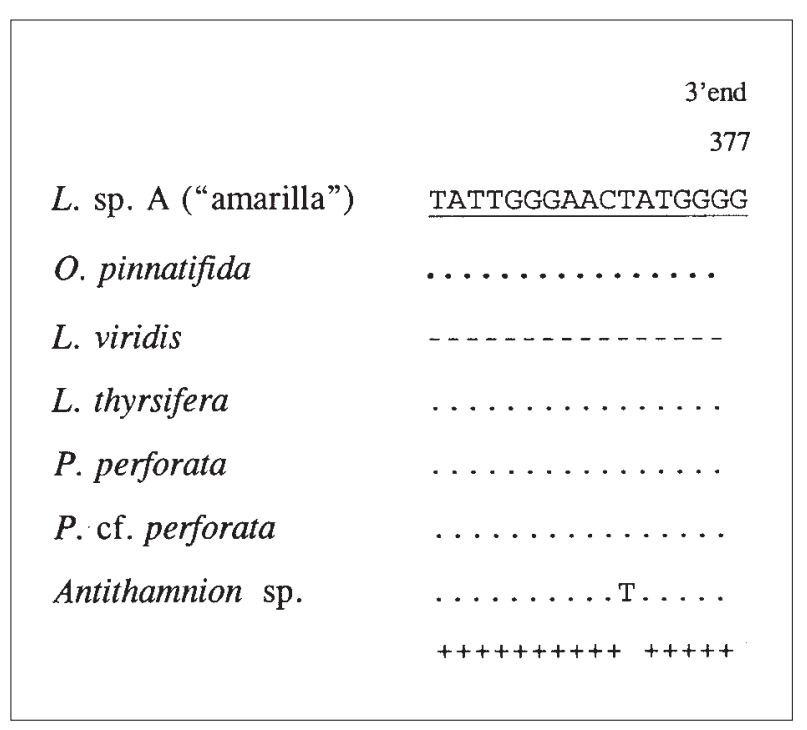

Fig. 2. (Continuation). shows a relatively high percentage identity of the spacer region between the Laurencia and Osmundea species $(72-83 \%)$ and across other genera (62.1-73.2 $\%)$ even though it is a non-coding region. Laurencia viridis and L. thyrsifera have very different geographical locations (Tenerife and New Zealand respectively), but still have a high sequence similarity for this spacer $(95.4 \%)$. The two species are morphologically very similar with the exception that $L$. viridis is green in color and L. thyrsifera reddish/purple. This high degree of conservation of primary sequence of the RUBISCO spacer has been noted in other algae (Valentin \& Zetche, 1990; Destombe \& Douglas, 1991; Goff \& al., 1994; Stache-Grain \& al., 1997) and it has been hypothesized that this conservation of sequence is as a result of the secondary structures in the plastid spacer perhaps having a role in tRNA maturation (Destombe \& Douglas, 1991). The AT content 
(a)

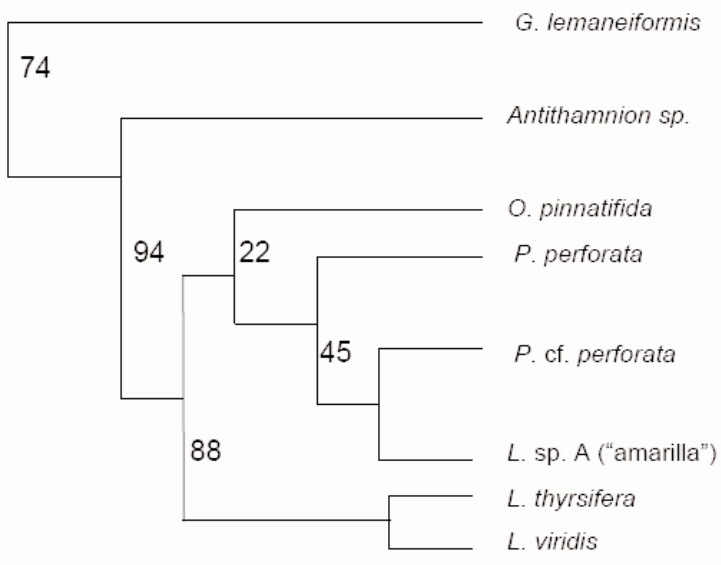

(b)

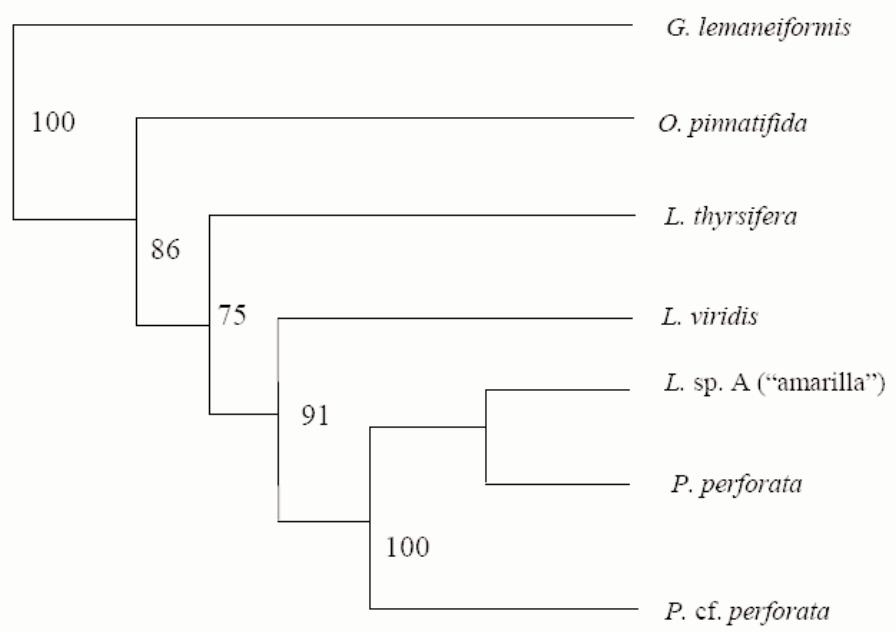

Fig. 3. Phylogenetic tree result from the DNAPENNY analysis of the RUBISCO spacer and its flanking coding regions (a) and of the ITS1, $5.8 \mathrm{~S}$ and ITS2 regions (b).

for the spacer in the Laurencia, Osmundea and Palisada species ranges between $76-80 \%$, which is similar to other algal species as Cryptomonas sp., Olisthodiscus luteus and Pylaeilla littoralis (Goff \& al., 1994; Douglas \& Durnford, 1989; Delaney \& Cattolico, 1989; Assali \& al., 1991).

Towards the 3' end of the spacer in all the Laurencia, Osmundea and Palisada species examined, there is a purine rich sequence ( ${ }^{\prime}$ AAGGAG $\left.{ }^{3}\right)$, corresponding to the ribosome binding site (Shine \& Dalgarno, 1974), upstream of the $r b c S$ coding region. This sequence, which has been found in all algae studied so far, contributes to the high conservation of the spacer region (Destombe \& Douglas, 1991). The initiation codon of the $r b c S$ in these algae GTG (GUG) is a sequence used at only $3-4 \%$ of the frequency of $A U G$ in bacteria (Reddy \& al., 1985). The open reading frames (ORF's) of $r b c \mathrm{~L}$ and $r b c \mathrm{~S}$ from the sequence data obtained from the algae were compared and there is a high percentage identity of these regions in all the algae with no insertions or deletions of bases (Fig. 4). There are equal numbers of transitions and transversions overall but there are a higher number of substitutions in the $r b c S$ than the $r b c \mathrm{~L}$, a situation also observed by Goff \& al. (1994).

Analysis of the multiple alignment of the RUBIS- $\underline{r b c \mathrm{~L}}$

L. sp. A ("amarilla") CGPLQTALDLWKDITFNYTSTDTADFVETPTANV

o. pinnatifida

L. viridis

L. thyrsifera

$P$. perforata

$P$. cf. perforata

G. lemanaeiformis

Antithamnion sp.

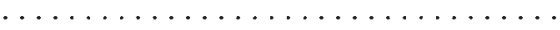

$\ldots \ldots \ldots \ldots$. L . . . . . . . .

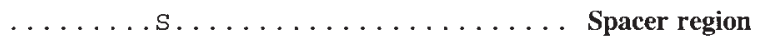

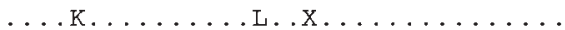

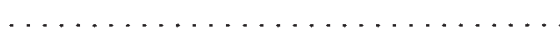

$\ldots \ldots \ldots \ldots \ldots \ldots \ldots \ldots \ldots$

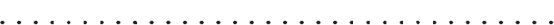

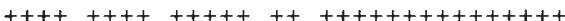

$\underline{r b c S}$

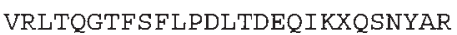

..................V. . . X

$\ldots \ldots \ldots \ldots \ldots \ldots$ K.IE. I

$\ldots \ldots \ldots \ldots \ldots$ KSIT. . X

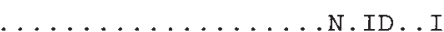

$\ldots \ldots \ldots$ K.IA. . V

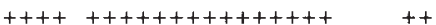

Fig. 4. Aligned sequences of ITS1, $5.8 S$ and ITS2 regions from Laurencia and Osmundea species. Sequences were aligned using the CLUSTALV programme and in some areas adjusted by eye. Dots denote the same nucleotide as that of Laurencia sp. A ("amarilla") in row one, $a$ * denotes the same nucleotide in all the Laurencia and Osmundea species, a hyphen represent a gap while a x represents an unknown nucleotide. The $5.8 \mathrm{~S}$ coding region is highlighted in bold. Lower case letters at the beginning and end of the alignment represent the $18 \mathrm{~S}$ and $28 \mathrm{~S}$ coding regions respectively. The forward and reverse primers are underlined. 


\begin{tabular}{|c|c|}
\hline L. sp. A ("amarilla") & FXXWAINIEYTDDPHPRNNYWELW \\
\hline O. pinnatifida & $\mathrm{XKN} \cdot \mathrm{XX}, \ldots \ldots \mathrm{XXT}, \ldots \ldots$ \\
\hline \multicolumn{2}{|l|}{ L. viridis } \\
\hline L. thyrsifera & SQN. . . . . . . . \\
\hline$P$. perforata & $x x x \ldots \ldots \ldots \ldots \ldots \ldots$ \\
\hline$P$. cf. perforata & sNs $\ldots \ldots \ldots \ldots$ s. $\ldots$ \\
\hline \multicolumn{2}{|l|}{ G. lemanaeiformis } \\
\hline Antithamnion sp. & SQN . . . . F . . . . . . . \\
\hline
\end{tabular}

Fig. 4. (Continuation).

CO spacer sequence data by maximum-likelihood (Fig. 3) indicates that the Laurencia, Osmundea and Palisada species appear to split into two branches with $L$. viridis and L. thyrsifera grouped together and $O$. pinnatifida, P. perforata, $P$. cf. perforata and $L$. sp. A ("amarilla") forming the other. The evolution of the two spacers at different rates was also seen in the two closely related Gracilariales genera Gracilaria Greville and Gracilariopsis Dawson (Goff \& al., 1994). Even though the plastid and nuclear spacers studied in the Laurencia, Osmundea and Palisada species have similar percentage identities (72-95.4\% and 70.3-98.7\% respectively) the RUBISCO spacer is quite highly conserved across genera, Our results confirm the position of Palisada cf. perforata in the taxon P. perforata. In addition, Laurencia sp. A ("amarilla") is separated from Osmundea but close to Palisada, these results are different to found in the "classical" morphological approach. Additional analysis is necessary to evaluate the exact taxonomical positions of these groups.

With respect to the nuclear sequences, we found that with the exception of $O$. pinnatifida, the ITS length ranged between 160 and 170 base pairs for ITS1 while ITS2 was larger by 37-62 base pairs, resulting in lengths between 202 -222 base pairs (Fig. 5). This greater length for ITS2 is seen in other red algae such as species of Gracilariopsis Dawson and Gracilaria Greville (Goff \& al., 1994). The comparison of se-

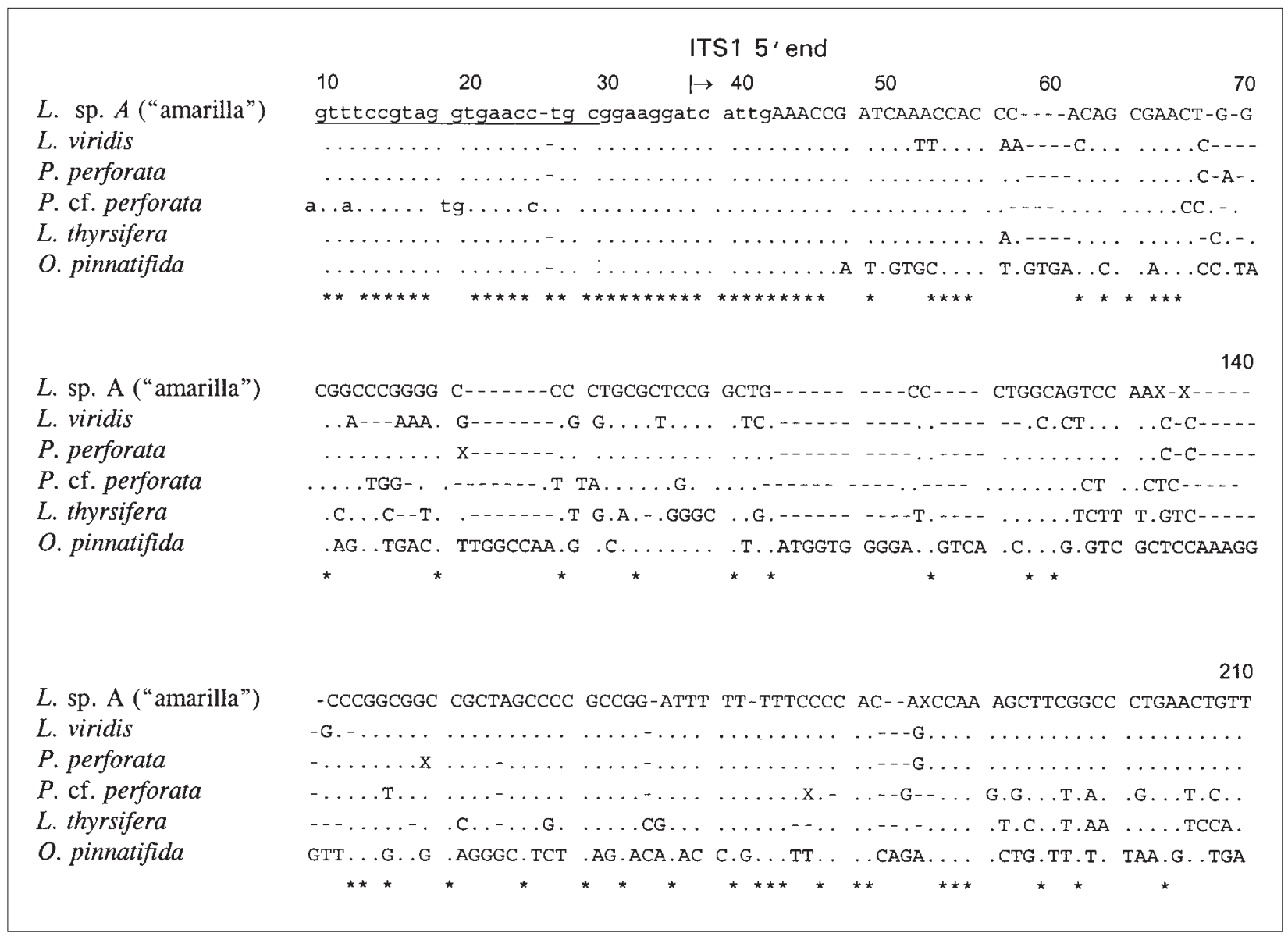

Fig. 5. Aligned sequences of $r b c L$ and $r b c S$ regions from Laurencia and Osmundea species. Sequences were aligned using the CLUSTALV programme same that figure 4. 
L. sp. A ("amarilla")

L. viridis

$P$. perforata

$P$. cf. perforata

L. thyrsifera

o. pinnatifida

L. sp. A ("amarilla")

L. viridis

$P$. perforata

$P$. cf. perforata

L. thyrsifera

o. pinnatifida

L. sp. A ("amarilla")

$L$. viridis

$P$. perforata

$P$. cf. perforata

L. thyrsifera

O. pinnatifida

\section{$\rightarrow$}

ATCGTACGGA - CACCGCCC GGCGACTCAA CCGAGATAAC TCTCAACAAC GGATATCTTG GCTCTCGCAA

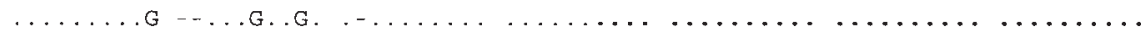

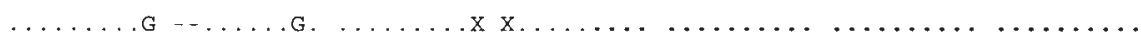
$\ldots \ldots$ АA.G - . С.

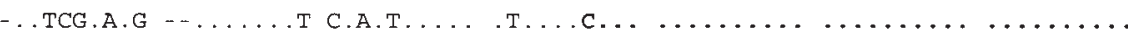

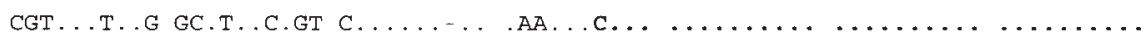

CGATGAAGAA CGCAGCGAAA TGCGATACGT AGTGTGAATT GCAGAATTCC GTGAATCATC GAATCTITGA

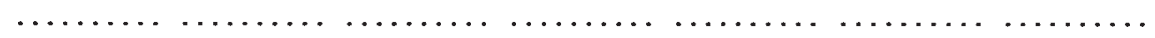

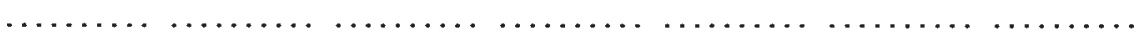

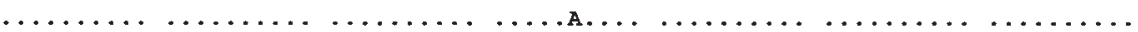

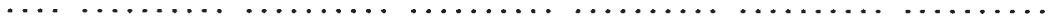

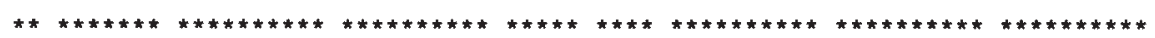

$5.8 \mathrm{~S}$ end

1 ACGCACATTG CGGTCGAGGC TTCGGCCGA ACCACGCCTG CCTCAGCGTC GGAATACACC CTCAATCCCC

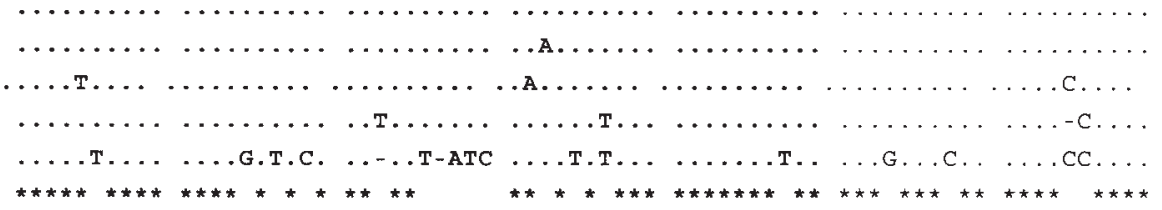

Fig. 5. (Continuation)

L. sp. A ("amarilla")

L. viridis

$P$. perforata

$P$. cf. perforata

L. thyrsifera

o. pinnatifida

L. sp. A ("amarilla")

L. viridis

P. perforata

$P$. cf. perforata

L. thyrsifera

$O$. pinnatifida

L. sp. A ("amarilla")

L. viridis

$P$. perforata

$P$. cf. perforata

L. thyrsifera

O. pinnatifida
TCCCCCGGAC ACTGGACGGT GGAGCGGGCT TGGAACTGGC CTCC--CGGT GGCGCGTACC GCACCGGGCT

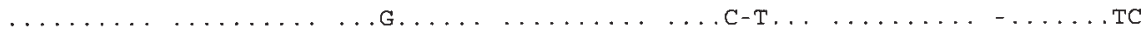

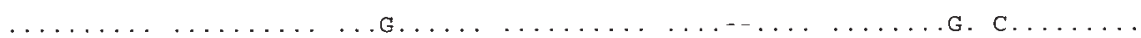

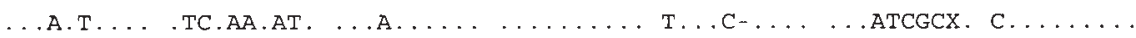

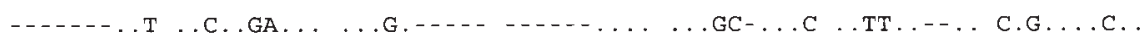

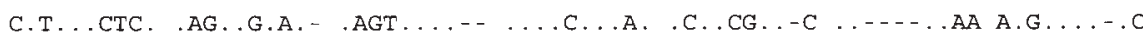

GGCTGAAGAT CAGAGGCTCC CGCACG-ACC CG-TCGAGGC CG--CGGTTA GGTAGGTGGC ATCGCTACTG

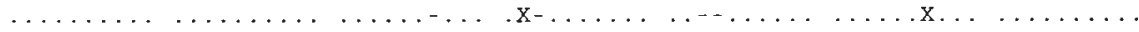

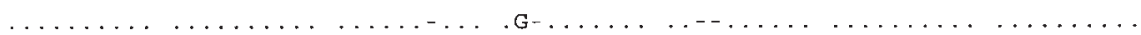

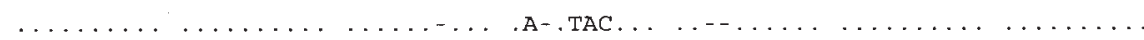

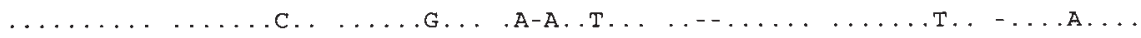
.T..... G....A..- G.XG. GC.T TGA.T.GC. . .GCTA.G.. .......T C.GA.T..C

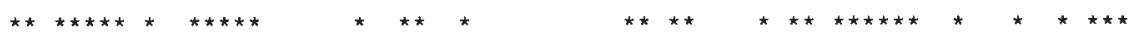
ITS2 $\leftarrow 1 \quad 630$ CTAGCTGGAG GCCGGGTACT GCTGGC--Ag CCCGCAGG.T CTATTC-GTT CATCGACCTG AGTTCAGACg

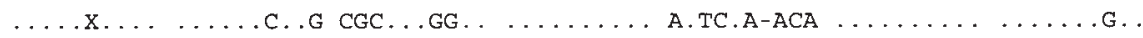

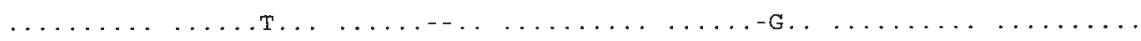
$\ldots \ldots \ldots \ldots$.

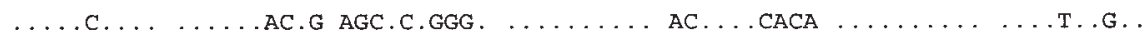

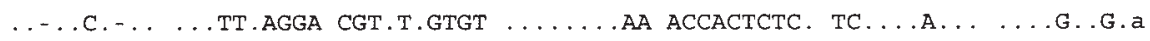

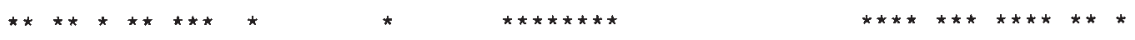

Fig. 5. (Continuation) 


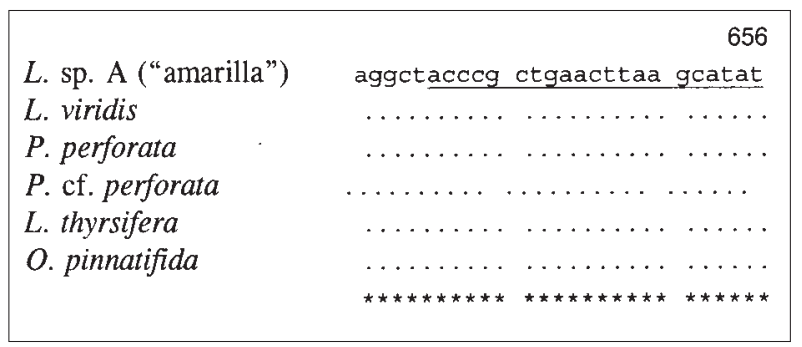

Fig. 5. (Continuation).

quence data obtained for each species of Laurencia and Osmundea shows a relatively high percentage identity within each of the three ITS/5.8S regions. Where differences between sequences occurred, 63\% of the changes were substitutions. ITS1 was more variable than ITS2, with $52.2 \%$ variable positions compared with $42 \%$ in ITS2. Furthermore, nucleotide deletions, which accounted for $37 \%$ of all differences, were most common in ITS1. Baldwin
(1992) reported that overall, ITS2 sequences were usually less variable than ITS1 sequences in some members of the Asteraceae, but there is also documentation to the contrary (Zechman \& al., 1994; O'Donnell, 1992). Zechman \& al. (1994) reported that in Stephanodiscus clones (diatoms), the ITS1 had $7.02 \%$ variability including insertions/deletions) while the ITS2 had $8.85 \%$ variability; however, this difference is not great considering that these are spacer regions.

The $5.8 \mathrm{~S}$ coding region has the highest similarity between species which might be expected as the sequence is more likely to be conserved than the noncoding internal transcribed spacers (Table 3). The degree of identity of the $5.8 \mathrm{~S}$ between the genera Laurencia and Osmundea (91.7-99.3\%) is consistent with values for the percentage identity within the genus Gracilaria of $94-98.7 \%$, the lowest identities being between O. pinnatifida and the Laurencia species (Table 4). Hence, the $5.8 \mathrm{~S}$ is highly conserved within a genus but less so between genera. However, the non-coding
5.8S L. sp. A ("amarilla")

$5.8 \mathrm{~S}$ L. viridis

5.8S $P$. perforata

$5.8 \mathrm{~S} P$. cf. perforata

5.8S L. thyrsifera

$5.8 \mathrm{~S} O$. pinnatifida

5.8S G. lemaneiformis

5.8S L. sp. A ("amarilla")

$5.8 \mathrm{~S}$ L. viridis

5.8S $P$. perforata

5.8S P. cf. perforata

$5.8 \mathrm{~S}$ L. thyrsifera

5.8S $O$. pinnatifida

5.8S G. lemaneiformis

5.8S L. sp. A ("amarilla”)

$5.8 \mathrm{~S} L$. viridis

5.8S $P$. perforata

5.8S P. cf. perforata

5.8S L. thyrsifera

5.8S $O$. pinnatifida

5.8S G. lemaneiformis

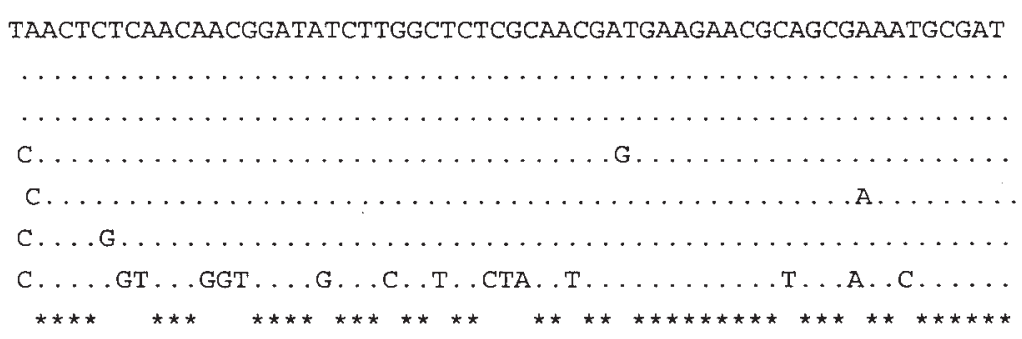

ACGTAGTGTGAATTGCAGAATTCCGTGAATCATCGAATCTTTGAACGCACATTGCGGTCG
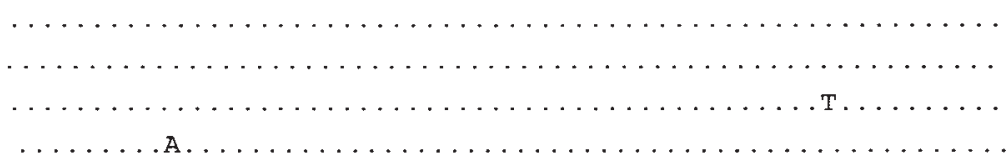

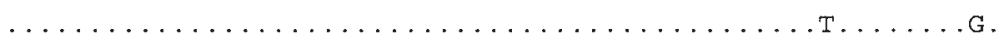

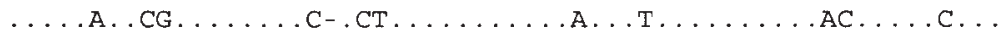

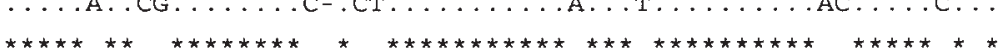

AGGCTTCGGCCGAGACCACGCCTGCCTCAGCGTC

$\ldots \ldots \ldots \ldots \ldots \ldots \ldots \ldots$

$\ldots \ldots \ldots \ldots \ldots \ldots \ldots \ldots$

$\ldots \ldots \ldots \ldots \ldots \ldots \ldots \ldots \ldots \ldots$

$\ldots \ldots$. . . . . . . . . . . . . . . .

T.C..... T-ATC...T.T....... . .

C. .G.AA.C...TG.G. T.T. .TT.G. . . .

* $\quad * * * * \star * \star * \star * *$

Fig. 6. Multiple alignment of $5.8 \mathrm{~S}$ sequences produced by CLUSTALV. A dot denotes the same nucleotide as that of Laurencia sp. A ("amarilla"), * represents the same nucleotide in all seven species, a hyphen represents a gap and a $\mathrm{x}$ represents an unknown nucleotide. 
regions displayed a comparatively high degree of similarity between species implying that there may be constraints on these regions as well.

The multiple alignment of the $5.8 \mathrm{~S}$ sequence data of the four Laurencia species (Fig. 6) shows that the majority of the differences in sequence are towards the 3' end of the coding region. This concurs with results from other genera in which the 3' region of $5.8 \mathrm{~S}$ is less conserved than the 5' end (Steane \& al., 1991, based on Mindell \& Honeycut, 1990). It is interesting to note that in Osmundea pinnatifida the $5.8 \mathrm{~S}$ coding region ends in the sequence TTC rather than GTC which is seen in the Laurencia species, as well as the majority of red algae.

In conclusion, the phylogenetic trees derived from the plastid and nuclear sequences of the Laurencia, Osmundea and Palisada species were different, which would imply that the three genomes are evolving at different rates (Goff \& al., 1994). However, all of the trees and sequence data do indicate that $O$. pinnatifi$d a$ has the least similarity to the Laurencia species and hence is the most distantly related. Nam \& al. (1994) proposed that $O$. pinnatifida, along with certain other Laurencia species, should be moved from the genus Laurencia into the resurrected genus Osmundea. The data presented here would support this proposal.

\section{Acknowledgements}

This work is in memory of Prof. Dr Peter Gacesa. This work has been partially supported by Project Actions Intergrades Hispano Britannica's n ${ }^{\circ} 285$.A. We would also like to thank M.C. Hernández González for her assistance and Dr R. Falshaw for provided New Zealand sample.

\section{References}

Assali N., Martin W., Sommerville \& Loiseaux-de Goer S. 1991. Evolution of the Rubisco operon from prokaryotes to algae. Structure and analysis of the $\mathrm{RbcS}$ gene of the brown algae $P y$ laeilla littoralis. Plant Molecular Biology 17: 853-863.

Bakker, F., Olsen, J. \& Stam, W. 1995. Evolution of Nuclear rDNA ITS sequences in the Cladophora albida/sericea Clade (Chlorophyta). Journal of Molecular Evolution 40: 640-651.

Baldwin, B. 1992. Phylogenetic utility of the internal transcribed spacers for nuclear ribosomal DNA in plants: an example from the Compositae. Molecular Phylogenetics and Evolution 1:3-16.

Beauchamp, K. \& Powers, D. 1996. Sequence variation of the first internal spacer (ITS-1) of ribosomal DNA in ahermatypic corals from California. Molecular marine biology and biotechnology 5: 357-362.

Cassano, V., M.T. M. Szechy \& M.T. Fujii. 2006. Laurencia caduciramulosa (Ceramiales, Rhodophyta) from Ilha Grande Bay, Rio de Janeiro, Brazil: a recent introduction into the Atlantic Ocean? Cryptogamie, Algologie 27(3): 265-277.

Coleman, A., Suarez, A. \& Goff, L. 1994. Molecular delineation of species and syngens in Volvocacean green algae (Chlorophyta). Journal of Phycology 30: 80-90.

Cordeiro-Marino, M., Toyota Fuji, M. \& Yamaguishi-Tomita, N. 1983. Morphological and Cytological studies on Brazilian Laurencia. 1: L. arbuscula Sonder (Rhodomelaceae, Rhodophyta). Rickia 10: 29-39.

Cribb, A.B. 1983. Marine Algae of the Southern Great Barrier Reef. Part l. Rhodophyta. Australian Coral Reef Society, Brisbane, Handbook No. 2. 173 pp, 71 pls.

Delaney, T. \& Cattolico, R. 1989. Chloroplast ribosomal DNA organization in the chromophytic algae Olisthodiscus luteus. Current Genetics 15(3): 221-229.

Destombe, C. \& Douglas, S. 1991. Rubisco spacer sequence divergence in the rhodophyta algae Gracilaria verrucosa and closely related species. Current Genetics 19: 395-398.

Diaz-Piferrer M. 1970. Adiciones a la flora marina de Venezuela. Caribbean Journal of Science 10(3-4): 159-198.

Douglas, S. \& Durnford, D. 1989. The small subunit of ribulose1,5-bisphosphate carboxylase is plastid encoded in the chlorophyll c-containing algae Cryptomonas. Plant Molecular Biology 13: 13-20.

Druehl, L. \& Saunders, G. 1992. Molecular explorations in kelp evolution. In: Round, F.E. \& Chapman, D.J. (eds), Progress in Phycological Research Vol. 8. Dan Hua Printing Press Co. Ltd, Hong Kong, pp. 47-78

Furnari, G, Boissett, F, Cormaci, M \& Serio, D. 2002. Characterization of Chondrophycus tenerrimus (Cremades) comb. nov. (Ceramiales, Rhodophyta), a species often misidentified as C. papillosus (C. Agardh) Garbary \& J. Harper in the Mediterranean Sea. Cryptogamie, Algologie 23: 223-235.

Furnari, G., Cormaci, M. \& Serio, D. 2001. The Laurencia complex (Rhodophyta, Rhodomelaceae) in the Mediterranean Sea: an overview. Cryptogamie, Algologie 22:331-373.

Garbary, D.J \& Harper, J.T. 1998. A phylogenetic analysis of the Laurencia complex (Rhodomelaceae) of the red algae. Cryptogamie Algology 19(3): 185-200.

Gil-Rodríguez, M.C. \& Haroun, R. 1992. Laurencia viridis sp nov. from the macaronesia Region. Botanica Marina 35(3): 227-237.

Gil-Rodríguez, M.C. \& Haroun, R. 1993. A view about the problematic in Laurencia (Rhodomelaceae, Rhodophyta) in the Canary Islands. Courier Forschungsinstitut Senckenberg 159: 113 117.

Goff, L., Moon, D. \& Coleman, A. 1994. Molecular delineation of species and species relationships in the red algal agarophytes Gracilariopsis and Gracilaria (Graciariales). Journal of Phycology 30: 521-537.

Haroun, R. \& Prud'homme van Reine, W. 1993. A biogeographical study of Laurencia and Hypnea species of the Macaronesian Region. Courier Forschungsinstitut Senckenberg 159: 119-125.

Hernández-González, M.C., Gil-Rodríguez, M.C. \& Haroun, R. 1994. Existence of plants bearing tetrasporangia and spermatangial receptacles (mixed phases) in the genus Laurencia Lamouroux (Rhodomelaceae). Nova Hedwigia 59: 189-194.

Hommersand, M., Fredericq, S. \& Freshwater, D. 1994. Phylogenetic systematics and biogeography of the Gigatinaceae (Gigartinales, Rhodophyta) based on sequence analysis of rbcL. Botanica Marina 37: 193-203.

Klein, J. \& Verlaque, M. 2005. Laurencia caduciramulosa Masuda et Kawaguchi (Ceramiales, Rhodophyta), first record on the Mediterranean coast of France. Cryptogamie, Algologie 26: 209216.

Kono, M., Satoh, H., Okabe, Y., Abe, Y., Nakayama, K. \& Okada, M. 1991. Nucleotide sequence of the large subunit of Ribulose 
-1, 5- bisphosphate carboxylase / oxygenase from the green algae Bryopsis maxima. Plant Molecular Biology 17: 505-508.

Lawson, G. \& John, D. 1982. The marine algae and coastal environment of Tropical West Africa. Nova Hedwigia 70: 1-455.

Maggs, C. \& Hommersand, M. 1993. Seaweeds of the British Isles. Rhodophyta. Part 3a Ceramiales. The Natural History Museum, London, $444 \mathrm{p}$.

Magne, F. 1980. On the identity of Laurencia pinnatifida from Scandinavian coast. Xth International Seaweed Symposium. Glasgow.

McDermid, K. 1988. Laurencia from Hawaii Islands: Key annotated list, and distribution of the species. In: Abbott, I. (ed.), Taxonomy of Economic Seaweeds with reference to some Pacific and Caribbean species. Vol. II. California Sea Grant College Program, La Jolla, California. pp. 231-247.

Mindell, D. \& Honeycutt, R. 1990. Ribosomal - RNA in vertebrates - evolution and phylogenetic applications. Annual Review of Ecology and Systematics 21: 541-566.

Nam, K., Maggs, C. \& Garbary, D. 1994. Resurrection of the genus Osmundea with an emendation of the generic delineation of Laurencia (Ceramiales, Rhodophyta). Phycologia 33 (3): 384-395.

O’Donnell, K. 1992. Ribosomal DNA internal transcribed spacers are highly divergent in the phylogenetic ascomycete Fusarium sambucinum (Gibberella pulicaris). Current Genetics 22: 213-220.

Pichard, S., Campbell, L., \& Paul, J. 1997. Diversity of the ribulose bisphosphate carboxylase/oxygenase form gene (rbcL) in natural phytoplankton communities. Applied Environement Microbiology 63(9): 3600-3606.

Reddy, P., Peterkofsky, A. \& Mckenney, K. 1985. Translation efficiency of the Escherichia coli adenylate cyclase gene - mutating the UUG initiation codon to GUG or AUG results in increased gene expression. Proceedings of the National Academy of Sciences of the United States of America 82: 5656-5660.

Rodríguez de Rios, N. \& Saito, Y. 1982. Observaciones sobre el genero Laurencia en Venezuela. 1: Laurencia intermedia (Yamada) y Laurencia corallopsis (Montagne) Howe. Ernstia 11: 1-16.

Rumpf, R., \& al. 1996. Evolution consequences of the loss of photosynthesis in Chlamydomonadaceae: Phylogenetic analysis of Rrn18 (18s rDNA) in 13 Polytoma stains (Chlorophyta). Journal of Phycology 32: 119-126.

Saito, Y. 1964. Contribution to the morphology of the genus Laurencia of Japan. Bulletin of the Faculty of Fisheries Hokkaido University 5: 69-74.

Saito, Y. 1965. Contribution to the morphology of the genus Laurencia of Japan II. Bulletin of the Faculty of Fisheries Hokkaido University 15: 207-212.
Saito, Y. 1967. Studies on Japanese species of Laurencia with special reference to their comparative morphology. Memoirs of the Faculty of Fisheries. Hokkaido University Japan 15: 1-81.

Saito, Y. 1969. On morphological distinctions of some species of Pacific North American Laurencia. Phycologia 8: 85-90.

Shine, J. \& Dalgarno, L. 1974. The 3'-terminal sequence of Escherichia coli 16 S ribosomal RNA: complementarity to nonsense triplets and ribosome binding sites. Proceedings of the National Academy of Sciences of the United States of America 71: 13421346.

Stache-Grain, B., Muller, D. \& Goff, L. 1997. Molecular systematic of Ectoparpus and Kuckuckia (Ectocarpales, Phaeophyceae) inferred from phylogenetic analysis of nuclear and plastid-encoded DNA sequences. Journal of Phycology 33: 152-168.

Steane, D. \& al. 1991. Amplification of the polymorphic 5.8S rRNA gene from selected Australian Gigartinalean species (Rhodophyta) by polymerase chain reaction. Journal of Phycology 27: 758-762.

Valentin, K. \& Zetsche, K. 1990. Structure of the Rubisco operon from the unicellular red algae Cyanidium caldarium: Evidence for a polyphyletic origin of the plastids. Molecular and General Genetics 222: 425-430.

Vandermeulen, H., Garbary, D. \& Guiry, M. 1990. Laurencia minuta sp. nov. (Ceramiales, Rhodomelaceae) a diminutive red algae from the Gulf and Aqaba (Red Sea). British Phycology Journal 25: 237-244.

Wynne, M.J. \& Ballantine, D.L. 1991. Laurencia iridiscens sp. nov. Rhodomelaceae, Ceramiales) from the Caribbean Sea. Phycologia 30: 394-401.

Yoneshigue-Valentin, Y., Fujii, M.T. \& Gurgel, F.D. 2003. Osmundea lata (Howe \& Taylor) comb. nov. (Ceramiales, Rhodophyta) from southeastern Brazilian continental shelf. Phycologia 42: 301-307.

Zetsche, K., Valentin, K., Maid, U. \& Kostrzwa, M. 1991. Structure and sequence of plastid genes of red algae (Rhodophyta)Phylogenetic implications. Endocytobiosis Cell Research 8: 197-229.

Zechman, F., Zimmer, E. \& Therist, E. 1994. Use of Ribosomal DNA Internal Transcribed spacers for phylogenetic syudies in Diatoms. Journal of Phycology 30: 507-512.

Editor asociado: A. Flores Recibido: 30-I-2007

Aceptado: 21-XII-2007 